\title{
Initial experience with laparoscopic gastrectomy in a low-volume center
}

\author{
Düşük yoğunluklu bir merkezde ilk laparoskopik gastrektomi deneyimlerimiz
}

\author{
Recep Aktimur ${ }^{1}$, Süleyman Cetinkunar ${ }^{2}$, Kadir Yıldırım ${ }^{1}$, Eylem Odabaşı ${ }^{3}$, Ömer Alıcı ${ }^{4}$, \\ Adil Nigdelioğlü ${ }^{5}$ Nuraydın Özlem ${ }^{1}$
}

\begin{abstract}
Objective: Today, minimal invasive surgery has gained wide acceptance by general surgeons, even in complex oncological procedures. Despite the increased experience on laparoscopic distal gastrectomy, limited number of surgeons prefer laparoscopic total gastrectomy for proximal or middle-third gastric cancer, due to the concern of technical difficulties which can alter the quality of oncological outcomes.
\end{abstract}

Methods: We retrospectively analyzed gastric cancer patients who underwent curative intent laparoscopic gastrectomy by single surgeon from October 2013 to April 2014. Five total gastrectomy + D2 (-No 10 and 11d) and 1 distal gastrectomy + D2 lymphadenectomy were analyzed for patient demographics, pathological characteristics, morbidity and in-hospital mortality.

Results: The mean operating time was $255,8 \pm 37.2$ minutes. The mean blood loss was $121.6 \pm 20.4 \mathrm{ml}$. In all patients, RO resection were performed. The mean number of harvested lymph nodes were 22.6 \pm 7.3 . The median number of metastatic lymph nodes was $16(0-23)$. In one patient, less than 15 lymph nodes were retrieved. Complication rate was $33.3 \%(n=2)$. In one patient, who underwent laparoscopic distal gastrectomy, afferent loop syndrome developed. In another patient, who underwent total gastrectomy plus splenectomy a massive pulmoner embolism developed. The median hospital stay was 10 (6-18) days.

Conclusion: With increased experience in advanced laparoscopic procedures, laparoscopic total gastrectomy may be considered as the first line treatment approach for gastric cancer patient even in a low-volume center.

Key words: Gastric cancer, Laparoscopic gastrectomy, distal gastrectomy, total gastrectomy

\section{ÖZET}

Amaç: Günümüzde minimal invazif cerrahi genel cerrahlar tarafından kompleks onkolojik prosedürler için bile kullanılır hale gelmiştir. Ancak, laparoskopik distal gastrektomi deneyiminin artmasına rağmen, teknik zorlukların onkolojik sonuçları etkileyebileceği endişesi ile az sayıda cerrah total gastrektomi için laparoskopik yöntemi tercih etmektedir.

Yöntemler: Eylül 2013 ile Nisan 2014 arasında tek cerrah tarafından küratif amaçlı laparoskopik gastrektomi uygulanmış mide kanseri hastalarını retrospektif olarak değerlendirdik. 5 total gastrektomi + D2 (-No 10 ve 11d) ve 1 distal gastrektomi + D2 lenfadenektomi hastası, demografik özellikler, patolojik karakteristikler, morbidite ve hastane mortalitesi açısından değerlendirildi.

Bulgular: Ortalama ameliyat süresi 255,8 $\pm 37,2$ dakika, ortalama kan kaybı 121.6 $\pm 20.4 \mathrm{~mL}$ idi. Tüm hastalara $\mathrm{R} 0$ rezeksiyon uygulandı. Çıkartılan lenf nodu ortalaması 22,6 67,3 , metastatik lenf nodu ortancası $16(0-23)$ idi. 1 hastada 15 'ten az lenf nodu çıkartıldı. Komplikasyon oranı \%33,3 ( $n=2)$ idi; laparoskopik distal gastrektomi uygulanan bir hastada aferent loop sendromu gelişti; laparoskopik total gastrektomi ve splenektomi uygulanan diğer bir hastada masif pulmoner emboli gelişti. Ortanca hastanede kalım süresi 10 (6-18) gündü.

Sonuç: Laparoskopik cerrahi prosedürlerin uygulanmasında gelişen deneyim düzeyi ile birlikte, ileri gastrik kanser hastaları için, ileri laparoskopik işlemlerin az sayıda ve düşük yoğunlukta yapıldığı merkezlerde dahi laparoskopik total gastrektomi ilk düşünülecek tedavi seçeneği olabilir.

Anahtar kelimeler: Mide kanseri, laparoskopik gastrektomi, distal gastrektomi, total gastrektomi

\footnotetext{
${ }^{\prime}$ Samsun Education and Research Hospital, Department of General Surgery, Samsun, Turkey

${ }^{2}$ Adana Numune Education and Research Hospital, Department of General Surgery, Adana, Turkey

${ }^{3}$ Samsun Education and Research Hospital, Department of Radiation Oncology, Samsun, Turkey

${ }^{4}$ Samsun Education and Research Hospital, Department of Pathology, Samsun, Turkey

${ }^{5}$ Samsun Education and Research Hospital, Department of Gastroenterology, Samsun, Turkey
}

Yazışma Adresi /Correspondence: Recep Aktimur,

Samsun Research and Education Hospital, dept. of General Surgery, Samsun, Turkey Yesildere mah., Akca cad., Mimoza evleri, B/40, Atakum, Samsun, Turkey Email: recepaktimur@gmail.com

Geliş Tarihi / Received: 17.02.2015, Kabul Tarihi / Accepted: 13.03.2015

Copyright @ Dicle Tıp Dergisi 2015, Her hakkı saklıdır / All rights reserved 


\section{INTRODUCTION}

Today, minimal invasive surgery has gained wide acceptance by general surgeons, even in complex oncological procedures. Since the first laparoscopic gastrectomy (LG) for gastric cancer was performed in 1991 [1], the advantages of minimal invasive surgery were supported with better oncological outcomes. Once laparoscopic distal gastrectomy (LDG) showed several benefits over open distal gastrectomy (ODG) by means of less blood loss, shorter hospital stay, enhanced recovery, harvested lymph node number and decreased complication rate, laparoscopic gastrectomy indications were widened from early gastric cancer to advanced gastric cancer [2-6]. In Eastern Asia, gastric cancer incidence is high and surveillance programs are quite different from Europe and United States. In Japan and South Korea, nearly half of patients are presenting with $\mathrm{T} 1$ gastric cancer and the proportion of distally located cancer is high $[7,8]$. Despite the increased experience on LDG, limited number of surgeons are preferred laparoscopic total gastrectomy (LTG) for proximal or middle-third gastric cancer, due to the concern of technical difficulties related poor oncological outcomes.

Many of laparoscopic gastrectomy reports are originate from Asia, just like the data about extended lymphadenectomy on gastric cancer treatment. Relatively few studies are focused on LTG and more limited number of studies primarily focused on LTG for advanced gastric cancer. In Turkey, the majority of gastric cancer patients are diagnosed at an advanced stage and performed surgeries are more palliative than initially planned (63.3\%), so the rate of curative surgery is lesser than the rest of the world [9]. When all of these factors are taken into account, slow evolution of laparoscopic gastric cancer surgery in Turkey, understandable. Although, there are more experienced centers on cancer and advanced laparoscopy, to our knowledge, this is the first report of initial experience of laparoscopic gastrectomy for gastric cancer in Turkey.

\section{METHODS}

We retrospectively analyzed the data of gastric cancer patients who underwent curative intent laparoscopic gastrectomy between September 2013 to
April 2014. The study was approved by the local ethics committee. Six laparoscopic (1 distal, 5 total) gastrectomy for gastric cancer were analyzed regarding patients demographics, pathological characteristics, morbidity and mortality. All patients were given low molecule weight heparine (LMWH) preoperatively and during postoperative 2 months as prophylaxis. Exclusion criteria were, pathological diagnosis of severe dysplasia and gastrectomy for other causes. The American Joint Committee on Cancer TNM staging system, 7th edition, was used to assess the pathological stage of the tumors. As described in the new version of staging system, tumors arising at the esophagogastric junction, or arising in the stomach 5-cm or less from the esophagogastric junction and crossing the esophagogastric junction are staged using the same version of TNM system for esophageal carcinoma.

Surgery was performed with the patient positioned in supine, reverse Trendelenburg position. After entering the abdominal cavity from supraumbilically placed $10-\mathrm{mm}$ trocar, two 5 -mm ports in the right lateral position, one $5-\mathrm{mm}$ port in the left upper quadrant and one 12-mm port in the left midabdomen were placed in a $\mathrm{V}$-shaped arrangement. Once access was gained to the abdomen, full exploration was obtained for evidence of metastasis. Gastrocolic ligament was divided and the greater omentum was mobilized. The dissection along the greater curvature of the stomach was proceeded up to the level of the left crus with division of left gastroepiploic vessel at their origin and short gastric vessels at the splenic hilum. Right gastroepiploic vessels were divided at their origin and the first portion of the duodenum was mobilized. After the transection of the duodenum with endoscopic linear stapler, the stomach was reflected to the left upper side and the lymphadenectomy was initiated. Lymphadenectomy definition was made according to the Japanese gastric cancer treatment guidelines 2010 (ver. 3) [10]. A D2 lymphadenectomy for distal gastrectomy involved nodes were; $\mathrm{D} 1+8 \mathrm{a}$, $9,11 \mathrm{p}, 12 \mathrm{a}$, while for total gastrectomy involved nodes were; D1 $+8 \mathrm{a}, 9,10,11 \mathrm{p}, 11 \mathrm{~d}, 12 \mathrm{a}$. In our five cases, we performed total gastrectomy and D2 lymphadenectomy except number 10 and $11 \mathrm{~d}$ lymph nodes, thus defined our dissection as D2 (-No 10 and 11d), while in one patient we performed distal 
gastrectomy and D2 lymphadenectomy. After the lymphadenectomy was completed, right crus of the diaphragm was explored. The distal esophagus was mobilized and transected with endoscopic linear stapler. Esophagojejunal anastomosis was performed with OrVilTM (Covidien, Norwalk, CT) transoral delivery tube and a 25-mm EEA stapler. Vessel ligations were performed with hem-o-lok ligation system and/or 5-mm blunt- tip LigaSureTM (Covidien, Norwalk, CT) vessel sealing device. Specimen was extracted through enlarged supraumbilical incision through a wound protector.

Continuous data were presented as median and range or mean plus minus standard deviation (SD). Dichotomous and categorical data were presented as numbers with percentages. Frequency analyses were performed with the SPSS, version 16.00 (Chicago, IL, USA).

\section{RESULTS}

The mean age and the mean BMI were $57.8 \pm 8.2$ and $26.1 \pm 5.3$, respectively. Patients' gender distribution was similar; 3 male, and 3 female. ASA grading and the tumor location of the patients were presented in Table 1.

Table 1. ASA grading and the tumor location of the patients

\begin{tabular}{lc}
\hline & $\begin{array}{c}\text { Laparoscopic } \\
\text { gastrectomy } \\
(\mathrm{n}=6) \mathrm{n}(\%)\end{array}$ \\
\hline $\begin{array}{l}\text { ASA grade, } \mathrm{n}(\%) \\
\text { Grade I }\end{array}$ & $3(50)$ \\
Grade II & $3(50)$ \\
Location of the tumor, n (\%) & \\
Antrum & $1(16.7)$ \\
Corpus & $1(16.7)$ \\
Cardia & $3(50)$ \\
Esophagogastric junction & $1(16.7)$ \\
\hline
\end{tabular}

ASA: American Society of Anesthesiologists scoring system

In all patients, R0 resection were performed. The mean operating time was $255,8 \pm 37.2$ minute, and the mean blood loss was $121.6 \pm 20.4 \mathrm{ml}$. In one patient, splenectomy was performed for a suspicion of hilar invasion. After the pathological assessment, hilar invasion was confirmed in this patient.
In one patient, less than 15 lymph nodes were retrieved. The mean number of harvested lymph nodes was $22.6 \pm 7.3$. The median number of metastatic lymph nodes was $16(0-23)$. The mean tumor size was $6.8 \pm 2.7 \mathrm{~cm}$. Histopathological diagnosis of the tumors was adenocarcinoma in all patients. Pathological characteristics of the patients were presented in Table 2.

Table 2. Pathological characteristics of the patients

\begin{tabular}{cc}
\hline & $\begin{array}{c}\text { Laparoscopic } \\
\text { Gastrectomy } \\
(\mathrm{n}=6) \mathrm{n}(\%)\end{array}$ \\
\hline $\begin{array}{c}\text { Tumor invasion, gastric, } \mathrm{n}(\%) \\
\text { T1 }\end{array}$ & $1(16.7)$ \\
T2 & - \\
T3 & - \\
T4 & $3(50)$ \\
Tumor invasion, esophageal, $\mathrm{n}(\%)$ & \\
T1 & - \\
T2 & - \\
T3 & $2(33.3)$ \\
T4 & - \\
Nodal metastasis, gastric, $\mathrm{n}(\%)$ & \\
N0 & $2(33.7)$ \\
$\mathrm{N} 1$ & - \\
$\mathrm{N} 2$ & $4(66.3)$ \\
$\mathrm{N} 3$ & - \\
Stage, gastric, $\mathrm{n}(\%)$ & \\
0 & - \\
1 & $1(16.7)$ \\
2 & - \\
3 & $3(50)$ \\
Stage, esophageal, $\mathrm{n}(\%)$ & - \\
1 & $1(16.7)$ \\
2 & \\
3 & \\
\hline
\end{tabular}

Complication rate was $33.3 \%(\mathrm{n}=2)$. In one patient, who underwent laparoscopic distal gastrectomy, afferent loop syndrome developed. Patient's complaint improved after laparoscopic Braun anastomosis in postoperative 15th day. In another patient, who underwent total gastrectomy plus splenectomy, a massive pulmoner embolism developed in postoperative 8th day, despite continuing prophylaxis, and the patient died. The median hospital stay was 10 (6-18) days for all patients.

\section{DISCUSSION}

The present study intends to analyze one surgeon's initial experience in laparoscopic gastrectomy for 
advanced gastric cancer and to evaluate the feasibility of laparoscopic gastrectomy in a not-specialized center, such as our institution. Our first laparoscopic gastrectomy was performed in September 2013, in this seven months period, six, non-selected, consecutive patients were underwent laparoscopic gastrectomy. Our results showed longer operating time. In our limited experience, the first LTG was performed in $315 \mathrm{~min}$, while the last (6th) was performed in $250 \mathrm{~min}$. Jeong et al. published one of the largest LTG series of 118 patients, reporting a mean operating time was $292 \pm 88 \mathrm{~min}$ [11]. We believe that after accumulating more experience, operating time will decrease subsequently. The advantage of less blood loss with LTG compared to OTG was described previously [12]. We have also shown less blood loss $(121.6 \pm 20.4 \mathrm{~mL})$. Apart from well known results of LG regarding the operating time and blood loss, we subjectively observed a quicker recovery in our laparoscopic gastrectomy performed patients with comparable pathological characteristics of the specimens, morbidity and in-hospital mortality.

For oncological efficacy of the surgical treatment, the extent of lymph node dissection is utmost critical. In western countries some surgeons still prefer D1 dissection because of no survival advantage, but higher operative morbidity and mortality rates obtained with D2 dissection $[13,14]$. On the other hand, the high incidence of gastric cancer in Asian countries, makes Asian surgeons more competent in treating gastric cancer. Many eastern surgeons are recommending D2 dissection for long-term survival advantage [15-17]. In Japan and South Korea D2 dissection is the standard lymphadenectomy except for T1 tumors. Less extensive lymphadenectomies are generally performed in lower incidence countries, and it may be resulted in pathological understaging of the tumors. According to National Comprehensive Cancer Network (NCCN) Guidelines Version 2.2013, gastric resection should include D2 lymphadenectomy with a goal of examining at least 15 or greater lymph nodes. However, in analysis of the SEER database, only one-third of 18,043 resected gastric cancer patients found to had 16 or more lymph nodes examined [18]. The real proportion of adequate lymph node dissection seems far away from desired levels. A recent meta analysis, which was comparing LTG and OTG, 4 of 17 stud- ies, did not mention the retrieval of No. 10 lymph nodes. They analyzed the effect of No. 10 lymph nodes dissection on the number of harvested lymph nodes and found no statistical difference between LTG and OTG for No. 10 lymph node dissection [19]. We performed D2 (-No 10 and 11d) lymphadenectomy in all patients. In 5 of 6 patients more than 15 lymph node were retrieved. In our institution, pathology clinic examines lymph node dissection of resected specimen with standard manual manner after formalin fixation. When the number of detected lymph nodes is considered, the pathological LN dissection technique is important. We must be aware of aforementioned technique's limitation that, it uncovers significantly fewer LNs in colorectal cancer patients [20]. The mean number of harvested lymph node in our LG patients (22.6 \pm 7.3$)$ was similar [2123] $(24 \pm 12 / 26 \pm 3 / 23.1 \pm 8)$ or better than small-sized studies [24] (11.2 \pm 8.2$)$. But, our surgical dissection technique still needs to be evaluated for providing at least 15 lymph nodes for all patients. On the other hand, for a fair comparison of the dissections, we must remember that reported patient population of LG and lymphadenectomy has mostly originated from Asian patients who were younger, slimmer and healthier from western population.

Another issue is the learning curve of this complex surgery. A recent meta analysis has mentioned 50 LTG cases as a cut point for learning period [19]. In contrast with our results, they showed no operating time advantage with increasing experience in LTG, and concluded that laparoscopic gastrectomy is still a time-consuming procedure.

All patients who were recommended to undergo laparoscopic gastrectomy have accepted the operative technique. As we were familiar with open gastrectomy, we initiated limited clear liquids in postoperative day 1 , and increased the amount subsequently in all patients. All patients were early mobilized. In a subjective judgment of our clinic, despite longer operating time, laparoscopic gastrectomy patients seemed to recover more rapidly than the open gastrectomy patients. But we did not assess these subjective observation objectively.

Our complication rate was $33.3 \%$. Although, reported complication rates for LG were lower $(15.6 \%-24.6 \%)$, for this limited experience with six advanced staged patients, a slightly increased 
complication rates may be acceptable $[11,25]$. Also, we must note that, in a recent systemic review of laparoscopy-assisted gastrectomy (LAG), lower morbidity rate $(10.4 \%)$ was reported in 365 LAG patients [26]. The laparoscopy-assisted approach may enable this complex surgery more understandable for surgeons and to provide better outcomes.

One of our patients died in early postoperative period due to massive pulmoner embolism. She had locally advanced disease (pathologically proven cancer invasion of the splenic hilum), but she did not have any risk factor for the development of deep venous thrombosis. She was thin and very responsive to our early and rigorous postoperative mobilization strategies. Patient's relatives had no information about her possible thrombus related medical history. She developed massive pulmoner embolism in postoperative day 8 , in spite of appropriate prophylaxis and aggressive treatment she was died rapidly.

Our study has several limitations. Our sample size for laparoscopic gastrectomy was very small. On the other hand, the rate of curative gastric cancer surgery is very low in our country; therefore the applicability of this complex surgery to more advanced cases in a not-specialized center is still remarkable. Our follow up time was limited for an assessment of oncological qualification and longterm outcomes of a surgical technique. Also we did not analyze patients recovery after surgery, so the observed positive effect of laparoscopic surgery remains subjective.

In conclusion, in our patients, laparoscopic approach was associated with longer operating time and lower blood loss. In spite of more advanced stage of gastric cancer, pathological characteristics, morbidity and mortality were comparable with other small-sized laparoscopic series. Best to our knowledge, this is the first report of LG in Turkey. With increased experience in advanced laparoscopic procedures, laparoscopic total gastrectomy may be considered as the first line treatment approach for gastric cancer patients even in low-volume centers. To assess oncological value of laparoscopic approach well-designed, prospective, randomized clinical trials are necessary.

\section{REFERENCES}

1. Kitano S, Iso Y, Moriyama M, et al. Laparoscopy-assisted Billroth I gastrectomy. Surg Laparosc Endosc 1994; 4:146148.

2. Hur H, Jeon HM, Kim W. Laparoscopy-assisted distal gastrectomy with D2 lymphadenectomy for T2b advanced gastric cancers: three years' experience. J Surg Oncol 2008;98:515-519.

3. Hamabe A, Omori T, Tanaka K, et al. Comparison of longterm results between laparoscopy-assisted gastrectomy and open gastrectomy with D2 lymph node dissection for advanced gastric cancer. Surg Endosc 2012; 26:1702-1709.

4. Viñuela EF, Gonen M, Brennan MF, et al. Laparoscopic versus open distal gastrectomy for gastric cancer: a metaanalysis of randomized controlled trials and high-quality nonrandomized studies. Ann Surg 2012; 255:446-456.

5. Kim YW, Baik YH, Yun YH, et al. Improved quality of life outcomes after laparoscopy-assisted distal gastrectomy for early gastric cancer: results of a prospective randomized clinical trial. Ann Surg 2008; 248:721-727.

6. Lee JH, Han HS, Lee JH. A prospective randomized study comparing open vs laparoscopy-assisted distal gastrectomy in early gastric cancer: early results. Surg Endosc 2005; 19:168-173.

7. Ahn HS, Lee HJ, Yoo MW, et al. Changes in clinicopathological features and survival after gastrectomy for gastric cancer over a 20-year period. Br J Surg 2011;98:255-260.

8. Suzuki H, Gotoda T, Sasako M, et al. Detection of early gastric cancer: misunderstanding the role of mass screening. Gastric Cancer 2006;9:315-319.

9. Yalcin S, Gumus M, Kilickap S, et al. End-of-study results of Turkish gastric cancer patients from the global REGATE study. J BUON 2014; 19:377-387.

10. Association JGC. Japanese gastric cancer treatment guidelines 2010 (ver. 3). Gastric Cancer 2011;14:113-123.

11. Jeong O, Ryu SY, Zhao X-F, et al. Short-term surgical outcomes and operative risks of laparoscopic total gastrectomy (LTG) for gastric carcinoma: experience at a large-volume center. Surg Endosc 2012;26:3418-3425.

12. Xiong J-J, Nunes QM, Huang W, et al. Laparoscopic vs open total gastrectomy for gastric cancer: a meta-analysis. World J Gastroenterol 2013;19:8114-8132.

13. Bonenkamp JJ, Hermans J, Sasako M, et al. Extended lymph-node dissection for gastric cancer. N Engl J Med 1999;340:908-914.

14. Danielson H, Kokkola A, Kiviluoto T, et al. Clinical outcome after D1 vs D2-3 gastrectomy for treatment of gastric cancer. Scand J Surg 2007;96:35-40.

15. Maruyama K, Gunvén P, Okabayashi K, et al. Lymph node metastases of gastric cancer. General pattern in 1931 patients. Ann Surg 1989;210:596-602.

16. Noguchi Y, Imada T, Matsumoto A, et al. Radical surgery for gastric cancer. A review of the Japanese experience. Cancer 1989;64:2053-2062.

17. Cuschieri A, Weeden S, Fielding J, et al. Patient survival after D1 and D2 resections for gastric cancer: long-term 
results of the MRC randomized surgical trial. Surgical Cooperative Group. Br J Cancer 1999;79:1522-1530.

18. Wang J, Dang P, Raut CP, et al. Comparison of a lymph node ratio-based staging system with the 7 th AJCC system for gastric cancer: analysis of 18,043 patients from the SEER database. Ann Surg 2012;255:478-485.

19. Wang W, Zhang X, Shen C, et al. Laparoscopic versus open total gastrectomy for gastric cancer: an updated meta-analysis. PLoS One 2014; 9:e88753.

20. Poller DN. Method of specimen fixation and pathological dissection of colorectal cancer influences retrieval of lymph nodes and tumour nodal stage. Eur J Surg Oncol 2000;26:758-762.

21. Dulucq J-L, Wintringer P, Stabilini C, et al. Laparoscopic and open gastric resections for malignant lesions: a prospective comparative study. Surg Endosc 2005;19:933-938.

22. Du J, Zheng J, Li Y, et al. Laparoscopy-assisted total gastrectomy with extended lymph node resection for advanced gastric cancer--reports of 82 cases. Hepatogastroenterology 2010;57:1589-1594.

23. Kim HS, Kim BS, Lee IS, et al. Comparison of totally laparoscopic total gastrectomy and open total gastrectomy for gastric cancer. J Laparoendosc Adv Surg Tech A 2013;23:323-331

24. Hallet J, Labidi S, Bouchard-Fortier A, et al. Oncologic specimen from laparoscopic assisted gastrectomy for gastric adenocarcinoma is comparable to D1-open surgery: the experience of a Canadian centre. Can J Surg 2013;56:249255.

25. Huang K-H, Lan Y-T, Fang W-L, et al. Initial experience of robotic gastrectomy and comparison with open and laparoscopic gastrectomy for gastric cancer. J Gastrointest Surg 2012;16:1303-1310.

26. Ye L-y, Liu D-r, Li C, et al. Systematic review of laparoscopy-assisted versus open gastrectomy for advanced gastric cancer. J Zhejiang Univ Sci B 2013;14:468-478. 